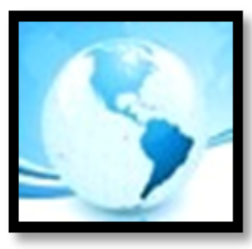

\author{
April 2018, VOLUME 6, ISSUE 2, 83 -109 \\ E-ISSN NO: $2289-4489$ \\ https://doi.org/10.22452/mojem.vol6no2.5
}

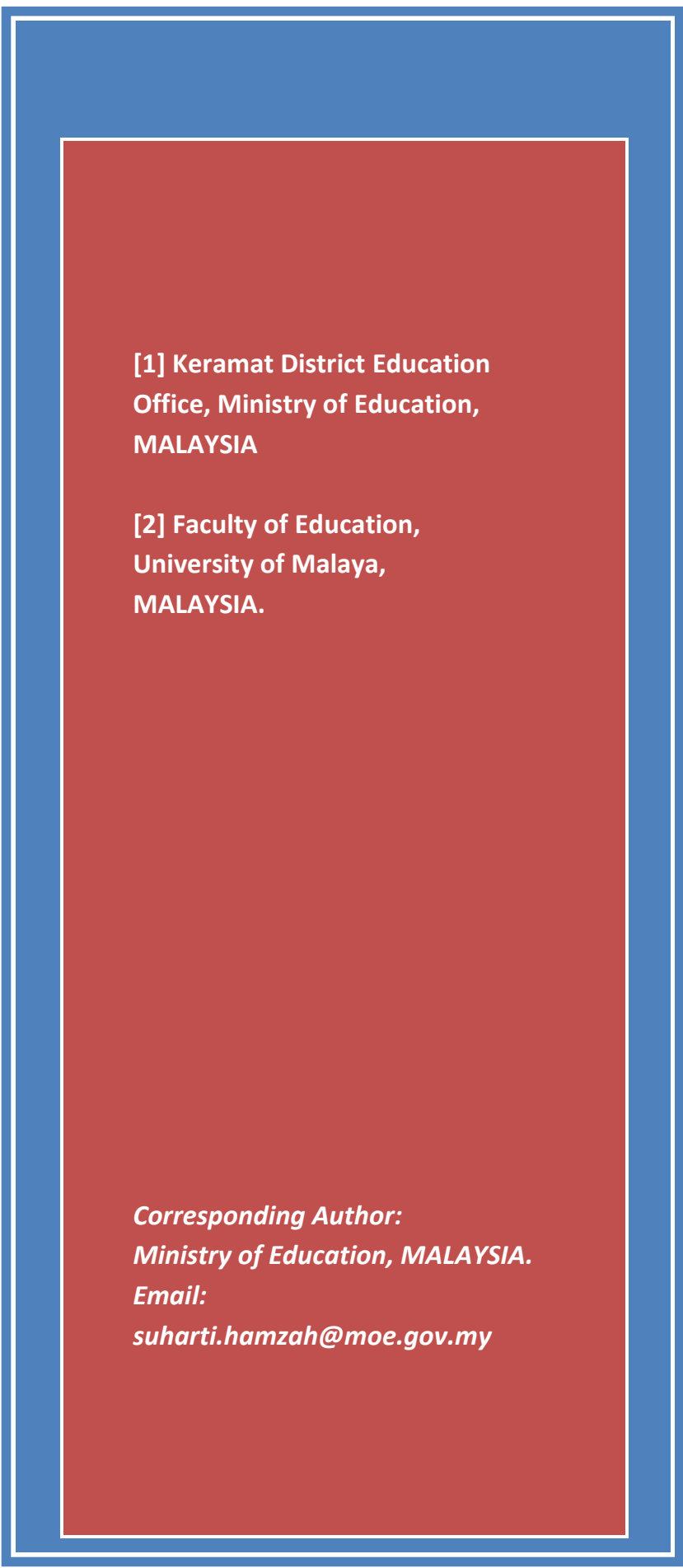

\title{
CHANGE ORIENTATION AND ORGANIZATIONAL CLIMATE: EXPERIENCE FROM MALAYSIAN PRIMARY SCHOOLS
}

Didy Suharti Hamzah ${ }^{1}$, Mohammed Sani Ibrahim ${ }^{2}$ (PhD) \& Simin Ghavifekr $^{2}(\mathrm{PhD})$

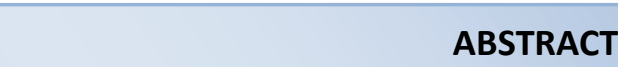

The aim of this study is to find the relationships that exist between change orientation and school organizational climate. This study also seeks to find the level of practice for the aspects in change orientation and school climate. The research samples for this quantitative research were taken from 246 teachers from national primary schools in Kuala Lumpur, Malaysia. The data were collected using the combination of two questionnaires namely Faculty Change Orientation Scale (FCOS) and the Organizational Climate Description Questionnaire for Elementary Schools (OCDQ-RE). The data were then analysed using descriptive and inferential statistics to test the research hypotheses. Findings indicate that the practice level of all three dimensions (faculty openness to change, principal openness to change and community press for change) in change orientation are high. Meanwhile, the practice level of five dimensions (supportive principal behaviour, directive principal behaviour, restrictive principal behaviour, collegial teacher behaviour and intimate teacher behaviour) in school climate are moderate and the other one dimension, (disengaged teacher behaviour) is low. In addition, the Multiple Linear Regression analysis showed one of the dimensions in change orientation (community press for change) has a significant relationship with school climate. Implication of the study shows that pressure for change from community outside school have direct impact on school climate. However, the aspect of support from school heads and intimate relationship among teachers need to be improvised as these are important dimensions that contribute to positive school climate. Some recommendations from this study are; to establish and maintain positive community relations, increase of school heads' support for teachers and to have strategic management approach in dealing with educational changes in schools.

Keywords: Organisational Climate, Change orientation, Primary schools, Education, Malaysia 


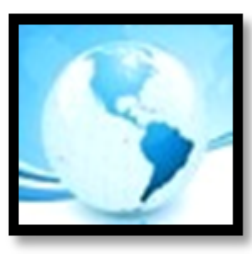

\section{MALAYSIAN ONLINE JOURNAL OF EDUCATIONAL MANAGEMENT (MOJEM)}

\section{INTRODUCTION}

Coping and dealing with the current changes and transformation is difficult and challenging in any sector including education. This is because change itself is complex and dynamic from various aspects which are the result of the current paradigm shift and new idealism in the world.

Change orientation and transformation in education are inevitable because we need to be able to meet the present and future challenges of the $21^{\text {st }}$ century. In this regard, education has become the top priority of any nations especially in the context of schools. This is because, as a social instrument; schools are where knowledge, values, and skills are taught to children and youth for the continuance of their way of lives and to develop their individual capacities for their future adult roles in the change-oriented society (Hussein Ahmad, 2012).

However, coping effectively with changes within educational organization such as school system is one of the most important skills required for the modern school management. Change is happening at all levels in the education system which transforms the way school leaders manage and lead the teaching and learning process. Many researchers and scholars in the field of change, a cknowledged the need for educational organizations especially schools to go through change initiatives (Fullan \& Suzanne, 1992; Fullan, 2010; Abdul Shukor, 2004; Elmore, 2004; Ghavifekr et al.,2013). In this regard, the focus is not only on the need to initiate change in schools, but also on its impact on those directly involved in the process of change, especially teachers. This is to manage the situation of teachers' resistance to the new alterations (Hayal Koksal, 2013). As a result, school leaders need to be aware of the key challenges of change management tasks as; being proactive to change, develop means for planned change, using proven procedures for controlling change and invest in innovation (Harris, 2013). Furthermore, as a leader of change, school management need to help teachers deal with the inherent challenges related to the change process. One of the key challenge in this regard is to help teachers in making the transition from having a change resistant mind-set, into acceptance and becoming proactive members of the change initiatives. This requires school leaders to acquire change management skills.

To meet these challenges, since 1990s, the Ministry of Education Malaysia had implemented various changes to the education system (Nor Hasnida et al., 2012). There are 14 planned changes for schools from 2003 to 2008 alone (Mohd Izham \& Sufean, 2007). These changes are implemented to the philosophy, direction, system, curriculum, pedagogy, method, roles of educational institutions, communication, culture and climate, student affairs, school personnel's, finance, technology, infrastructure and school management and leadership (Sharifah \& Samsilah, 2009).

Currently, the education system in Malaysia is undergoing large changes and transformations through the recent Malaysian Education Blueprint, 2013-2025. The initiative aims to improvise or change the current education system in response to the need to produce quality human capital. This involves changes and new initiatives in the education system which has direct impact on schools and community within and surrounding them. The blueprint signifies the ideals and expectations of Malaysians on the country's education system. The blueprint positions the system and students' aspirations in its initiatives to change, transform and improvise the current education system in response to the challenge of having quality education of world class. One of the aims of the blueprint is to make schools as high performing hubs for knowledge and virtue. As a result, schools are involved in continuous planned change as organizations and individual systems within them. Change must be implemented in both institutional and individual systems in order for the school leaders, teachers, students and the community to aim 


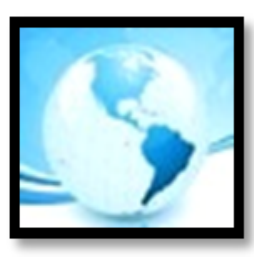

\section{MALAYSIAN ONLINE JOURNAL OF EDUCATIONAL MANAGEMENT (MOJEM)}

towards quality and effective education of the globalization era. Therefore, this study attempts to investigate the relationships of change orientation in schools and school climate. In addition, this study seeks to add to the extant literature by exploring the constructs and relationship of change orientation and organizational climate at the primary school level.

Although these changes are intended to improve the education system, only a handful of schools are successful in implementing them. Majority of the schools are still underachievement and ineffective (Nor Hasnida et al., 2012). Moreover, teachers in schools may perceive change as vague and are misguided which then lead to resistance or failed implementation. Resistance also happens because teachers view the change initiatives as mandated and it does not come from within them. It is important to take note that the education system in Malaysia is highly centralized; its education policy, curricular, initiatives and programs are mandated by the central agency the Ministry of Education, State Education Departments and District Education Offices. This could often lead to rejection or considered as unsustainable change initiatives. Therefore, there is a pertinent need to study change orientation in schools and its impact on school climate. Moreover, with the increased importance given to student achievement, school leaders should understand how to successfully promote, implement and sustain change initiatives.

Researchers and experts on organizational change and school climate have highlighted the significance of studying both aspects to improve student achievement (Evans, 1996; Fullan, 1995; Huy, 2001; James \& Connolly, 2000; Smith, 2002). Since the need for research on organizational change and school climate is pertinent, this study pursues to investigate their relationships. This study aims to identify the possible relationships between three aspects of change orientation and six dimensions of organizational climate. More specifically, the study focuses to address problems in regards to: (i) determining the level of practice for the aspects in change orientation among school heads and teachers in primary schools; (ii) determining the level of practice for the aspects in school organizational climate among school heads and teachers in primary schools; and (iii) determining the relationship existing between change orientation and school climate in primary schools.

\section{CONCEPTUAL FRAMEWORK}

The framework for this study is developed to determine the relationship between teachers change orientation and school climate. It is developed based on the combination of these two models: Change Dimensions (Kearney \& Smith, 2008) and Dimensions of Elementary School Climate (Hoy Tarter \& Kottkamp, 1991). The study on the components of change orientation in schools is based on the Change Dimensions (Kearney \& Smith, 2008). There are three main dimensions of change orientation. These dimensions measure school's perceptions of the three important aspects of change in a school. The dimensions are described below:

a) Faculty Openness to Change - Teachers' receptivity to change

b) Principal Openness to Change - School leader's orientation to change

c) Community Press for Change - Receptivity of internal stakeholders to externally pressed changes

The theory of organizational climate in schools was originally conceptualized by Halpin and Croft (1966) through the development of the Organizational Climate Description Questionnaire (OCDQ). However, Halpin and Croft's conceptual model of climate and instrument (OCDQ) has been subjected to criticisms and revisions (Hoy, Tarter \& Kottkamp, 1991). To improvise the original OCDQ, Hoy, Tarter and Kottkamp (1991) had revised it through the findings of 


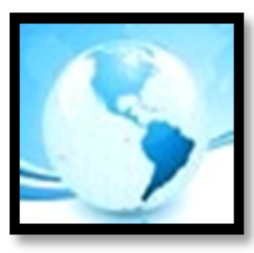

their research. The objectives of their research was to study the relevancy of the items in OCDQ, to find out which items are dependable indicators of the defined dimensions of climate and provide insights whether there is a need of new conceptualization of climate.

Hoy, Tarter and Kottkamp (1991) had significantly modified Halpin and Croft's school climate instrument. The modified instrument is called the Organizational Climate Description Questionnaire-RE (OCDQ-RE) which describes the behaviour of primary school teachers and principals. This modification leads to the classification of the six new dimensions of school climate. Three of the dimensions are to describe principal behaviour (leadership): (i) supportive principal behaviour; (ii) directive principal behaviour; (iii) restrictive principal behaviour. Meanwhile, the remaining three are to depict teacher behaviour (interaction): (iv) collegial teacher behaviour; (v) intimate teacher behaviour; and (vi) disengaged teacher behaviour.

Based on the discussions presented in this paper, the concepts and models described above have significant relationship and relevancy with each other and the topics being researched. Thus, they are used as the conceptual framework of this study. The conceptual framework has three independent variables from the school change dimensions (i) faculty openness to change, (ii) principal openness to change, and (iii) community press for change. The six dependent variables from the dimensions of elementary school change are (a) principal behaviour including (i) supportive, (ii) directive, and (iii) restrictive and (b) teacher behaviour which includes: (i) collegial, (ii) intimate, and (iii) disengaged. The theoretical framework of this study is portrayed as in Figure 1 below: 


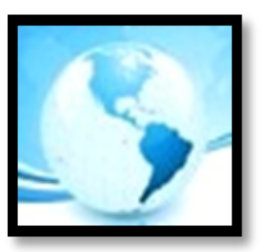

INDEPENDENT VARIABLE
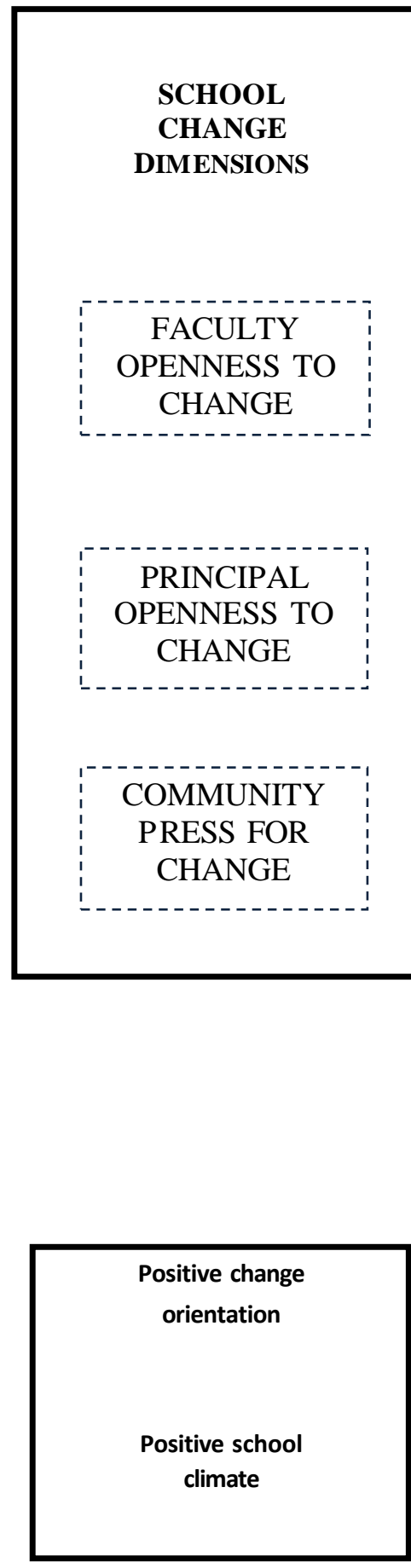

MALAYSIAN ONLINE JOURNAL OF

EDUCATIONAL MANAGEMENT

(MOJEM)

\section{DEPENDENT VARIABLE}

DIMENSIONS OF PRIMARY SCHOOL CLIMATE PRINCIPAL BEHAVIOUR:

Supportive Principal Behaviour

I. The principal uses constructive criticism.

II. The principal compliments teachers.

III. The principal listens to and accepts teachers' suggestions.

\section{Directive Principal Behaviour}

I. The principal monitors everything teachers do.

Effe ct

II. The principal rules with an iron fist.

III. The principal checks lesson plans

\section{Restrictive Principal Behaviour}

I. Teachers are burdened with busy work.

II. Routine duties interfere with the job of teaching.

III. Teachers have too many committee requirements.

\section{TEACHER BEHAVIOUR:}

Collegiall Teacher Behaviour

I. Teachers help and support each other.

II. Teachers respect the professional competence of their colleagues.

III. Teachers accomplish their work with vim, vigor, and pleasure.

Intimate Teacher Behaviour

I. Teachers socialize with each other.

II. Teachers' closest friends are other faculty members at this school.

III. Teachers have parties for each other. Disengaged Teacher Behaviour

I. Faculty meetings are useless.

II. There is a minority group of teachers who always oppose the majority.

III. Teachers ramble when they talk at faculty meetings.

Figure 1: Conceptual Framework (Kearney \& Smith, 2008; Hoy, Tarter \& Kottkamp, 1991) 


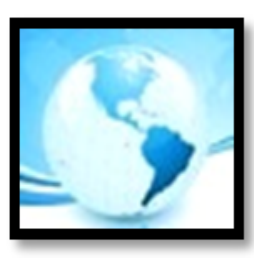

\section{METHOD}

\section{Research Design}

The research method of this study was quantitative which allowed the researchers to collect data through a set of survey questionnaire. This involves the process of questionnaire selection, data collection and data analysis. Descriptive statistical analysis was used to explain the demographical profile of the respondents and the independent and dependent variables in this study. Meanwhile, inferential statistical analysis of Multiple Linear Regression analysis was utilized to determine the relationship between school change orientation and school organizational climate.

\section{Population and Sampling}

The population of this study consisted of the teachers from national primary schools in the Keramat District, Kuala Lumpur Federal Territory. A total of 246 school teachers from eight national primary schools in the district were selected randomly as the samples for this study. The sampling procedure used in this study was the stratified sampling procedure where teachers were selected randomly based on the schools which were stratified into clusters geographically. The 34 national primary schools in the Keramat District were clustered according to their location; north, south, east and west of the district and the schools from each cluster were also randomly selected. The researchers chose national primary schools in this district because of the strategic location and learning environment. Being situated in the heart of the capital city of Malaysia, primary schools in this district are more exposed to the current education changes either initiated by the ministry, the state education department, district education office or other stakeholders. The primary schools here are also more exposed to the latest innovation and technology due to being located in of one of the most developed city in Asia. Moreover, these schools are also prone to being influenced to changes in various other areas such as politics, economic and social. In these intense educational changes, technological development and other influences, the climate of schools in this district is unique and exposed to challenges which schools in other states might not be experiencing.

\section{Instrumentation}

The instrument used in this study were the combination of two tested questionnaires including: Change Orientation Scale (COS) developed by Kearney and Smith (2008) and the Organizational Climate Description Questionnaire for Elementary Schools (OCDQ-RE) developed by Hoy, Tarter and Kottkamp (1991). Teachers are required to choose the most suitable response to each statement presented in the questionnaire based on the direction given. The instrument consists of three sections as follows:

\footnotetext{
A: Demographic profile of respondents (gender, age category, teaching experience, and highest education level)

B: Statements on change orientation

C: Statements on school climate
}

To test the reliability and validity of the items, Cronbach's alpha test was used. As shown in Table and 2, the value for Cronbach's alpha for this study indicated an acceptable internal consistency of the items in each scale. Hence, the instrument was reliable for the study. 


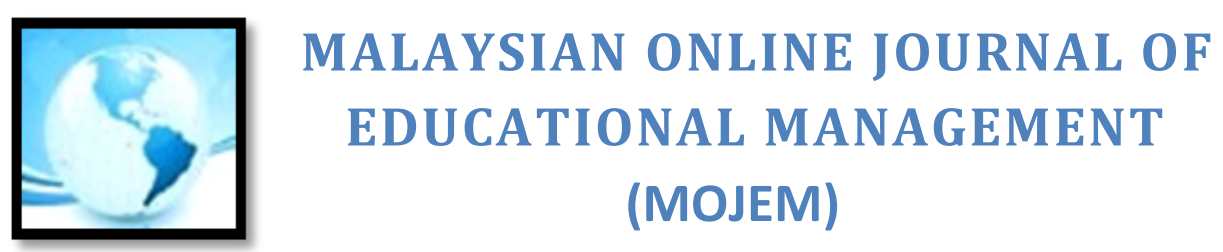

Table 1

Reliability test for Change Orientation

\begin{tabular}{lcc}
\hline \multicolumn{1}{c}{ Variables } & Number of items & Cronbach's Alpha \\
\hline Openness to Change & 9 & .840 \\
Principal Openness to Change & 6 & .746 \\
Community Press for Change & 4 & .733 \\
\hline
\end{tabular}

Note: 4 items recorded from Faculty Openness to Change and 4 items recorded from Principal Openness to Change

Table 2

Reliability test for School Climate

\begin{tabular}{lcc}
\hline \multicolumn{1}{c}{ Variables } & Number of items & Cronbach's Alpha \\
\hline Supportive Principal Behaviour & 9 & .935 \\
Directive Principal Behaviour & 9 & .740 \\
Restrictive Principal Behaviour & 5 & .763 \\
Collegial Teacher Behaviour & 8 & .710 \\
Intimate Teacher Behaviour & 7 & .776 \\
Disengaged Teacher Behaviour & 4 & .729
\end{tabular}

Note: 2 items recorded from Collegial Behaviour and 1 item recorded from Restrictive Behaviour

As shown above, (Tables 1 \& 2) the Cronbach's Alpha for every construct in the change orientation and school climate are greater than 0.7 , thereby confirming that there is good internal consistency of items in each scale.

\section{Data Collection and Analysis}

The researchers had obtained permission from the Education Planning and Research Division, Ministry of Education and the Kuala Lumpur Federal Territory Education Department to conduct this study in primary schools in the Keramat District. The questionnaires were distributed by the researchers to the selected schools. By doing this, the researchers were able to explain the objectives of this study and at the same time help teachers with instructions on filling the questionnaires. Teachers' anonymity and confidentiality of all responses was confirmed. With school administrators' assistance, teachers were randomly selected as respondents to this study. The introduction, explanation, distribution, completion and collection of questionnaires ranged from 30-40 minutes per school. However, in some schools, the researchers had to collect the questionnaires in few days' time because of several circumstances such as time or unavailability of school administrators. Some schools even had the filled questionnaires posted to the researchers. Each school selected for this study were given 35 sets of questionnaires with a total of 246 questionnaires (87.85\%) returned to the researchers within one month. This shows a satisfactory data collection (Kerlinger, 1986).

The collected data were analysed using the Statistical Package of the Social Sciences (SPSS/ Version 21). The data were analysed using both descriptive analysis (Mean and standard deviation) and inferential statistical analysis (Multiple Linear Regression) to achieve the aim and objectives of this study. 


\section{FINDINGS}

\section{Demographic Profile of Respondents}

The four demographic profiles of respondents that were analysed are: gender, age, years of teaching experience and highest level of education. Table 3 below summarises the results of the demographic profiles of the respondents in number and percentages.

Table 3

Demographic Profile of the Respondents

\section{Demographic Profile}

Frequency

Percent

\begin{tabular}{|c|c|c|c|}
\hline \multicolumn{4}{|l|}{ Gender: } \\
\hline & Female & 175 & 71.1 \\
\hline & Male & 71 & 28.9 \\
\hline \multicolumn{4}{|l|}{ Age: } \\
\hline & $20-30$ years old & 49 & 19.9 \\
\hline & $31-40$ years old & 81 & 32.9 \\
\hline & $41-50$ years old & 91 & 37.0 \\
\hline & More than 51 years old & 25 & 10.2 \\
\hline \multicolumn{4}{|c|}{ Years of Teaching } \\
\hline \multirow[t]{4}{*}{ Experience: } & $1-10$ years & 50 & 20.3 \\
\hline & $11-20$ years & 76 & 30.9 \\
\hline & $21-30$ years & 95 & 38.6 \\
\hline & 31 years and above & 25 & 10.2 \\
\hline \multirow{2}{*}{\multicolumn{4}{|c|}{$\begin{array}{l}\text { Highest Level of } \\
\text { Education: }\end{array}$}} \\
\hline & & & \\
\hline & Teaching Certificate & 1 & 4 \\
\hline & Diploma & 21 & 8.5 \\
\hline & Bachelor's degree & 197 & 80.1 \\
\hline & Master's degree & 27 & 11.0 \\
\hline & Doctorate (PhD) & 0 & 0 \\
\hline
\end{tabular}

Findings show that majority of the respondents are female teachers because there are 175 females (71.1\%) and 71 males (28.9\%) recorded in the sample, giving a total of 246 respondents. Majority of the respondents are between $41-50$ years old $(37.0 \%)$, followed by $31-40$ years old $(32.9 \%), 20-30$ years old $(19.9 \%)$ and only $10.2 \%$ of them is more than 51 years old.

Results show that $38.6 \%$ or 95 teacher's respondents have worked for more than 21 - 30 years in the teaching line. In the meantime, $30.9 \%$ of the teacher's respondents have worked in the range of $11-20$ years, $20.3 \%$ of them have worked in the range of $1-10$ years. However, there are only $10.2 \%$ of the respondents who have the longest teaching experienced since they worked more than 31 years and above. And in terms of the highest educational level held by the respondents, the highest percentage of respondents comes from bachelor's degree level which is $80.1 \%$. Meanwhile, $11 \%$ of the sample respondents already in the Master level, while around $8.5 \%$ of them having a Diploma, and only one respondent holds a teaching certificate. 


\section{Practice Level of the Dimensions in Change Orientation}

The change orientation aspect consists of three dimensions that represent the level of openness and pressure toward change in schools. The three dimensions are namely faculty openness to change, principal openness to change and community press for change.

The overall outcome of the analysis on the dimensions of change orientation is as presented in Table 4. Findings of the analysis reveal that all three dimensions of change orientation (faculty openness to change, principal openness to change and community press for change) have high mean scores of $4.17,4.54$ and 4.22 respectively.

Table 4

Mean and Standard Deviation for the Dimensions in Change Orientation

\begin{tabular}{lccc}
\hline \multicolumn{1}{c}{ Variables } & Mean & Std. Deviation & Interpretation \\
\hline Faculty Openness to Change & 4.17 & .535 & High \\
Principal Openness to Change & 4.54 & .586 & High \\
Community Press for Change & 4.22 & .573 & High \\
\hline
\end{tabular}

However, the mean score of principal openness to change is the highest mean compared to faculty openness to change and community press for change. This finding indicates that all three important stakeholders of primary schools, namely teachers, school leaders and community are committed to change. This is because change is viewed as something that could not be avoided. Realization among the teachers, school leaders and community that change is needed for the current education environment is high.

In finding more in-depth analysis of the practice level for all of the dimensions in the change orientation aspect, the descriptive analysis of each dimension is provided in the subsequent sub-topics:

\section{- Level of Practices in Schools' Openness to Change Dimension}

This section consists of items that elicit feedback from the respondents about their perception on schools' openness to change. These items summarize the level of openness to change among teachers and leaders in schools. Table 5 describes the mean and standard deviation for all aspects in the faculty openness to change dimension.

The overall level of practices on the faculty openness to change dimension is high with the mean score of 4.17 and standard deviation of .535. This indicates that most of the teachers have positive and open perception toward change initiatives. Most of the teachers expressed that they are not in favour in dealing with changes in schools with confrontation. The aspects of resisting major change, rejecting big change and rhetoric of change are found to be in moderation. 


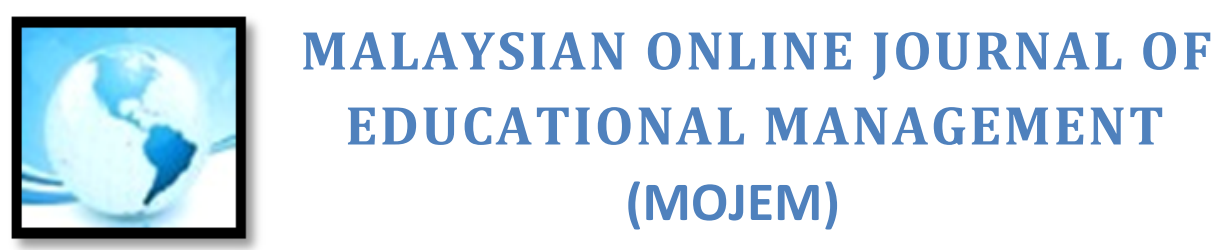

Table 5

Mean and Standard Deviation for the Aspects in the School Openness to Change Dimension

\begin{tabular}{|c|c|c|c|}
\hline Aspects & Mean & $\begin{array}{l}\text { Standard } \\
\text { Deviation }\end{array}$ & Interpretation \\
\hline Teachers welcome change & 4.24 & .649 & High \\
\hline Teachers embrace new ideas & 4.29 & .579 & High \\
\hline Teachers receptive to substantial change & 3.91 & .651 & High \\
\hline Major change is resisted & 2.94 & .812 & Moderate \\
\hline Teachers accept changes to rules and procedures & 3.92 & .587 & High \\
\hline Teachers reject all but minimal change & 2.99 & .803 & Moderate \\
\hline Rhetoric of change is strong & 2.61 & .860 & Moderate \\
\hline Teachers rather fight than switch & 2.17 & .753 & Low \\
\hline Teachers relish innovation & 4.25 & .617 & High \\
\hline Overall Level of Practices in & 4.17 & .535 & High \\
\hline Faculty Openness to Change & & & \\
\hline
\end{tabular}

\section{- Level of Practices in Principal Openness to Change Dimension}

This section consists of items that give feedback from the respondents about their perception on school heads' openness to change. These items summarize the level of openness to change among headmaster/headmistress in schools. Table 6 describes the mean and standard deviation for all aspects in the principal openness to change dimension.

Table 6

Mean and Standard Deviation for the Aspects in the Principal Openness to Change

\begin{tabular}{lccc}
\multicolumn{1}{c}{ Aspects } & Mean & Standard & Interpretation \\
& & Deviation & Moderate \\
\hline Principal balks at new suggestions & 2.40 & .754 & Moderate \\
Principal is slow to change & 2.55 & .881 & High \\
Principal is committed to major change & 4.37 & .673 & Moderate \\
Principal resist changes suggested by parents & 2.47 & .778 & High \\
Principal embraces change initiatives & 4.37 & .706 & Low \\
Principal committed to no change & 1.87 & .691 & High \\
\hline Overall Level of Practices in & 4.54 & .586 & \\
Principal Openness to Change & & & \\
\hline
\end{tabular}

Table 6 above shows the overall level of practices on the principal openness to change dimension is high with the mean score 4.54 and standard deviation .586. This indicates that most of the teachers perceive their school's headmaster/headmistress as being supportive of change, open to initiatives in schools. Most of the teachers agree that their school's headmaster/headmistress is very committed to change efforts. However, aspects of hesitation to change, slow to change and resistance to change suggested by parents are found to be in moderation. 


\section{- Level of Practices in Community Press for Change Dimension}

This section consists of items that give feedback from the respondents about their perception on the community pressure on change. These items summarize the level of pressure given by the community on change implementation in schools. Table 7 describes the mean and standard deviation for all aspects in the community press for change dimension.

Table 7

Mean and Standard Deviation for the Aspects in the Community Press for Change

\begin{tabular}{lccc}
\multicolumn{1}{c}{ Aspects } & Mean & $\begin{array}{c}\text { Standard } \\
\text { Deviation }\end{array}$ & Interpretation \\
\hline School community pushes for innovation & 4.25 & .623 & High \\
Suggestions by PTA often produces change & 3.95 & .652 & High \\
Teachers are open to ideas of parents & 4.28 & .540 & High \\
Community members are happy with school & 4.47 & .657 & High \\
\hline Overall Level of Practices in & 4.22 & .573 & High \\
Community Press for Change & & & \\
\hline
\end{tabular}

Table 7 above shows the overall level of practices on the community press for change dimension is high with a mean score of 4.22 and standard deviation of .573. This indicates that most of the teachers perceive the community as putting a huge pressure on schools to implement change and innovation programmes. Most of the teachers are also found to agree that the community give the aspect of change a high priority. Community is also perceived as satisfied with the schools as a whole. One of the reasons for the satisfaction probably due to the schools being open to the community ideas and find them beneficial to be implemented.

\section{Practice Level of the Dimensions in School Climate}

The school climate aspect consists of six dimensions which represent the level of behaviour of multiple elements that contribute to climate of a school. The six dimensions are namely supportive principal behaviour, directive principal behaviour, restrictive principal behaviour, collegial teacher behaviour, intimate teacher behaviour and disengaged teacher behaviour.

Table 8

Mean and Standard Deviation for the Dimensions in School Climate

\begin{tabular}{lccc}
\hline \multicolumn{1}{c}{ Variables } & Mean & Std. Deviation & Interpretation \\
\hline Supportive Principal Behaviour & 2.79 & .442 & Moderate \\
Directive Principal Behaviour & 2.45 & .339 & Moderate \\
Restrictive Principal Behaviour & 2.91 & .435 & Moderate \\
Collegial Teacher Behaviour & 3.09 & .337 & Moderate \\
Intimate Teacher Behaviour & 3.23 & .373 & Moderate \\
Disengaged Teacher Behaviour & 1.65 & .451 & Low \\
\hline
\end{tabular}

The overall outcome of the analysis on the dimensions of school climate is presented in Table 8 above. Findings of the analysis show that five of the dimensions (supportive principal behaviour, directive principal behaviour, 


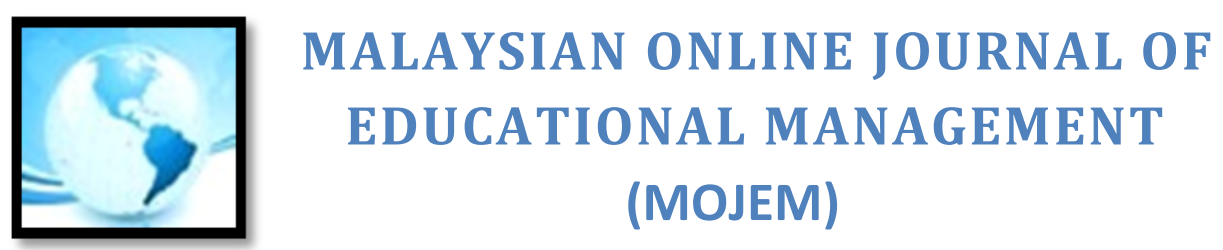

restrictive principal behaviour, collegial teacher behaviour, intimate teacher behaviour) have moderate mean scores of 2.79, 2.45, 2.91, 3.09 and 3.23 respectively. However, the mean score of disengaged teacher behaviour is low at 1.65 . The school heads are perceived by teachers to be reasonable at their supportive, directive and restrictive behaviours, however, they do not have a particular strong leadership style that is needed for more positive and open school climate. Neither have they had a strong leadership style that give negative impact on the climate of schools. The behaviours of the teachers are also found to be reasonable in their collegiality and intimacy with each other. In addition, the teachers are particularly very attached and committed to their profession and responsibilities. In finding more in-depth analysis of the practice level for all of the six dimensions in the school climate aspect, the descriptive analysis of each dimension is further provided in the subsequent sub-topics:

\section{- Level of Practices in Supportive Principal Behaviour Dimension}

This section consists of items that provide response from the respondents about their perception on the principal's supportive behaviour. These items summarize the level of support given by the headmaster/headmistress in schools. Table 9 below describes the mean and standard deviation for all aspects in the supportive principal behaviour dimension.

Table 9

Mean and Standard Deviation for the Aspects in the Supportive Principal Behaviour

\begin{tabular}{|c|c|c|c|}
\hline Aspects & Mean & $\begin{array}{l}\text { Standard } \\
\text { Deviation }\end{array}$ & Interpretation \\
\hline Principal helps teachers & 3.10 & .560 & Moderate \\
\hline Principal uses constructive criticism & 2.89 & .562 & Moderate \\
\hline Principal explains reasons for criticism & 2.63 & .610 & Moderate \\
\hline Principal listens to and accepts teachers' suggestions & 2.95 & .492 & Moderate \\
\hline Principal looks out for teachers' personal welfare & 2.91 & .549 & Moderate \\
\hline Principal treats teachers as equals & 2.26 & .589 & Low \\
\hline Principal compliments teachers & 3.00 & .671 & Moderate \\
\hline Principal is easy to understand & 2.82 & .480 & Moderate \\
\hline Principal shows appreciation to teachers & 2.81 & .658 & Moderate \\
\hline Overall Level of Practices in & 2.79 & .442 & Moderate \\
\hline Supportive Principal Behaviour & & & \\
\hline
\end{tabular}

The overall level of practices on the supportive principal behaviour dimension is moderate with a mean score of 2.79 and standard deviation of .442. This gives the indication that most of the teachers perceive their headmaster/headmistress as not providing them with enough emotional and psychological support. This lack of support from the school heads is likely due to several reasons which include the barrier that is put between them and the school heads who perceive themselves as more superior. This barrier is indicated by the low level for school heads treating the teachers as equals. 


\section{- Level of Practices in Directive Principal Behaviour Dimension}

This section consists of items that give feedback from the respondents about their perception on the principal's directive behaviour. These items summarize the level of directions given by the headmaster/headmistress in schools. Table 10 below describes the mean and standard deviation for all aspects in the directive principal behaviour dimension.

The overall level of practices on the directive principal behaviour dimension is moderate with a mean score of 2.45 and standard deviation of .339. This gives the indication that most of the teachers perceive their headmaster/headmistress as giving them minimal directions and supervision on their professional responsibilities and routine tasks. Moreover, aspects of implementing an iron fist leadership, scheduling work for teachers and autocratic leadership are found to be low. Although the school heads did not implement autocratic leadership, they did monitor and supervise teachers occasionally.

Table 10

Mean and Standard Deviation for the Aspects in the Directive Principal Behaviour

\begin{tabular}{lccc}
\multicolumn{1}{c}{ Aspects } & Mean & $\begin{array}{c}\text { Standard } \\
\text { Deviation }\end{array}$ & Interpretation \\
\hline Principal rules with an iron fist & 1.26 & .508 & Low \\
Principal checks the sign-in sheet every morning & 3.23 & .606 & Moderate \\
Principal schedules the work for the teachers & 2.13 & .748 & Low \\
Principal corrects teachers' mistakes & 3.00 & .447 & Moderate \\
Principal closely checks classroom (teacher) activities & 2.40 & .600 & Moderate \\
Principal supervises teachers closely & 2.57 & .557 & Moderate \\
Principal checks lesson plans & 3.04 & .456 & Moderate \\
Principal is autocratic & 1.82 & .603 & Low \\
Principal monitors everything teachers do & 2.38 & .602 & Moderate \\
\hline Overall Level of Practices in & 2.45 & .339 & Moderate \\
Directive Principal Behaviour & & & \\
\hline
\end{tabular}

\section{- Level of Practices in Restrictive Principal Behaviour Dimension}

This section consists of items that give feedback from the respondents about their perception on the principal's restrictive behaviour. These items summarize the level of restrictiveness implemented by the headmaster/headmistress in schools. Table 11 describes the mean and standard deviation for all aspects in the restrictive principal behaviour dimension. 


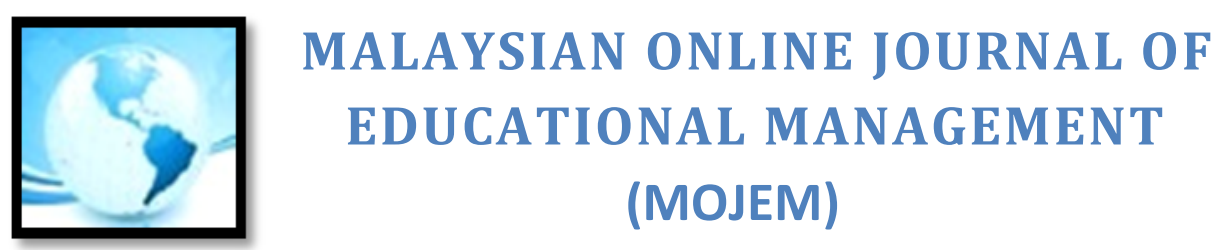

Table 11

Mean and Standard Deviation for the Aspects in the Restrictive Principal Behaviour

\begin{tabular}{lccc}
\multicolumn{1}{c}{ Aspects } & Mean & $\begin{array}{c}\text { Standard } \\
\text { Deviation }\end{array}$ & Interpretation \\
\hline Routine duties interfere with the job of teaching & 2.68 & .674 & Moderate \\
Teachers have too many committee requirements & 2.58 & .639 & Moderate \\
Administrative paperwork is burdensome & 2.89 & .623 & Moderate \\
Clerical support reduces teachers' paperwork & 1.81 & .833 & Low \\
Teachers are burdened with busy work & 3.00 & .572 & Moderate \\
\hline Overall Level of Practices in & 2.91 & .435 & Moderate \\
Restrictive Principal Behaviour & & & \\
\hline
\end{tabular}

The overall level of practices on the restrictive principal behaviour dimension is moderate with a mean score of 2.91 and standard deviation of .435. This gives the indication that most of the teachers perceive their headmaster/headmistress as giving them a moderate amount of workload in schools. Majority of the teachers feel that the amount of work they have to complete as teachers and staff is manageable. The level of support given by the school office's staff is perceived as low.

\section{- Level of Practices in Collegial Teacher Behaviour Dimension}

This section consists of items that give feedback from the respondents about their perception on the collegiality behaviour of teachers. These items summarize the level of collegiality among teachers in schools. Table 12 below describes the mean and standard deviation for all aspects in the restrictive collegial teacher behaviour dimension.

Table 12

Mean and Standard Deviation for the Aspects in the Collegial Teacher Behaviour

\begin{tabular}{llcc}
\multicolumn{1}{c}{ Aspects } & Mean & $\begin{array}{c}\text { Standard } \\
\text { Deviation }\end{array}$ & Interpretation \\
\hline $\begin{array}{l}\text { Teachers accomplish their work with vim, } \\
\text { vigour and pleasure }\end{array}$ & 3.22 & .512 & Moderate \\
Teachers leave school immediately after & 1.92 & .516 & Low \\
school is over & & .597 & Moderate \\
Teachers accept the faults of their colleagues & 2.79 & .574 & Moderate \\
Teachers help and support each other & 3.35 & .560 & Moderate \\
Teachers are proud of their school & 3.33 & .545 & Moderate \\
New teachers are readily accepted by colleagues & 3.41 & .659 & Moderate \\
Teachers socialize together in small, select groups & 2.71 & .510 & Moderate \\
Teachers respect the professional competence of their & 3.37 & & .337 \\
colleagues & & 3.09 & Moderate \\
\hline Overall Level of Practices in & & & \\
Collegial Teacher Behaviour & & & \\
\hline
\end{tabular}




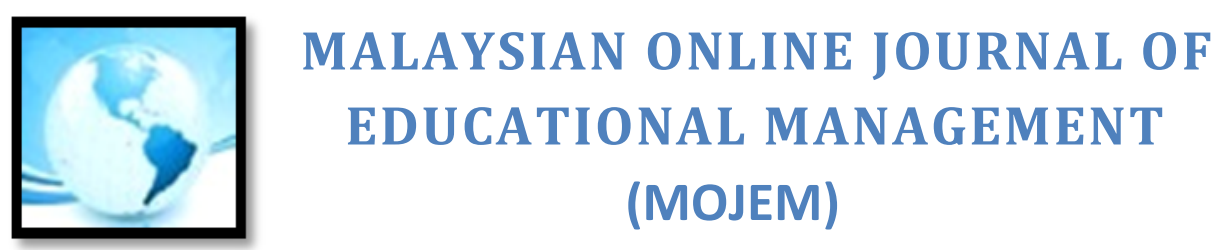

The overall level of practices on the collegial teacher behaviour dimension is moderate with a mean score of 3.09 and standard deviation of .337. This indicates that most of the teachers perceive other teachers in schools as having moderate feeling of togetherness and attachment as colleagues. However, teachers view themselves to be committed to their professional responsibilities as the level of the aspect of leaving immediately after school is over is low.

\section{- Level of Practices in Intimate Teacher Behaviour Dimension}

This section consists of items that give feedback from the respondents about their perception on the intimacy behaviour of teachers. These items summarize the level of intimacy among teachers in schools. Table 13 describes the mean and standard deviation for all aspects in the intimate teacher behaviour dimension.

Table 13

Mean and Standard Deviation for the Aspects in the Intimate Teacher Behaviour

\begin{tabular}{lccc}
\multicolumn{1}{c}{ Aspects } & Mean & $\begin{array}{c}\text { Standard } \\
\text { Deviation }\end{array}$ & Interpretation \\
\hline Teachers' closest friends are other teachers & 3.56 & .516 & Moderate \\
Teachers invite colleagues to visit them at home & 2.66 & .555 & Moderate \\
Teachers know the colleagues' family background & 2.76 & .478 & Moderate \\
Teachers have fun socializing with colleagues & 3.47 & .607 & Moderate \\
Teachers have parties for each other & 3.44 & .558 & Moderate \\
Teachers socialize with colleagues on regular basis & 3.50 & .528 & Moderate \\
Teachers provide strong social support for colleagues & 3.31 & .560 & Moderate \\
\hline Overall Level of Practices in & 3.23 & .373 & Moderate \\
Intimate Teacher Behaviour & & & \\
\hline
\end{tabular}

The overall level of practices on the intimate teacher behaviour dimension is moderate with a mean score of 3.23 and standard deviation of .373. This indicates that most of the teachers in the schools perceive themselves as having moderate feeling of intimacy and closeness as colleagues. In schools, teachers are friendly with one another but at the same time they maintain their professional relationships as to not be too personal and intimate.

\section{- Level of Practices in Disengaged Teacher Behaviour Dimension}

This section consists of items that give feedback from the respondents about their perception on the disengaged behaviour of teachers. These items summarize the level of engagement among teachers in schools. Table 14 describes the mean and standard deviation for all aspects in the disengaged teacher behaviour dimension.

Table 14

Mean and Standard Deviation for the Aspects in the Disengaged Teacher Behaviour

\begin{tabular}{|c|c|c|c|}
\hline Aspects & Mean & $\begin{array}{l}\text { Standard } \\
\text { Deviation }\end{array}$ & Interpretation \\
\hline Meetings are useless & 1.31 & .535 & Low \\
\hline Minority group of teachers oppose the majority & 1.87 & .605 & Low \\
\hline Teachers exert group pressure on non-conforming & 1.93 & .583 & Low \\
\hline
\end{tabular}




\begin{tabular}{llll}
\hline teachers & & & \\
Teachers ramble when they talk at meetings & 1.37 & .623 & Low \\
\hline $\begin{array}{l}\text { Overall Level of Practices in } \\
\text { Disengaged Teacher Behaviour }\end{array}$ & 1.65 & .451 & Low \\
\hline
\end{tabular}

The overall level of practices on the disengaged teacher behaviour dimension is low with a mean score of 1.65 and standard deviation of .451 . This indicates that most of the teachers perceive themselves as very engaged to their responsibilities as teachers and staff in school. They regard their professionalism highly and take their work seriously. The teachers are very committed and serious about everything that has to do with their roles as educators and staff in schools.

\section{Hypothesis Testing}

The hypothesis testing in this study was made using a statistical technique of multiple linear regressions to analyse the relationship between the dependent and independent variables. Each independent variable was weighted by the regression analysis procedure to ensure the maximum prediction from the set of independent variables. Figure 2 below simplifies the five stages, in providing a graphical representation of the model building process for multiple regressions. The following sections discuss each step-in detail. 


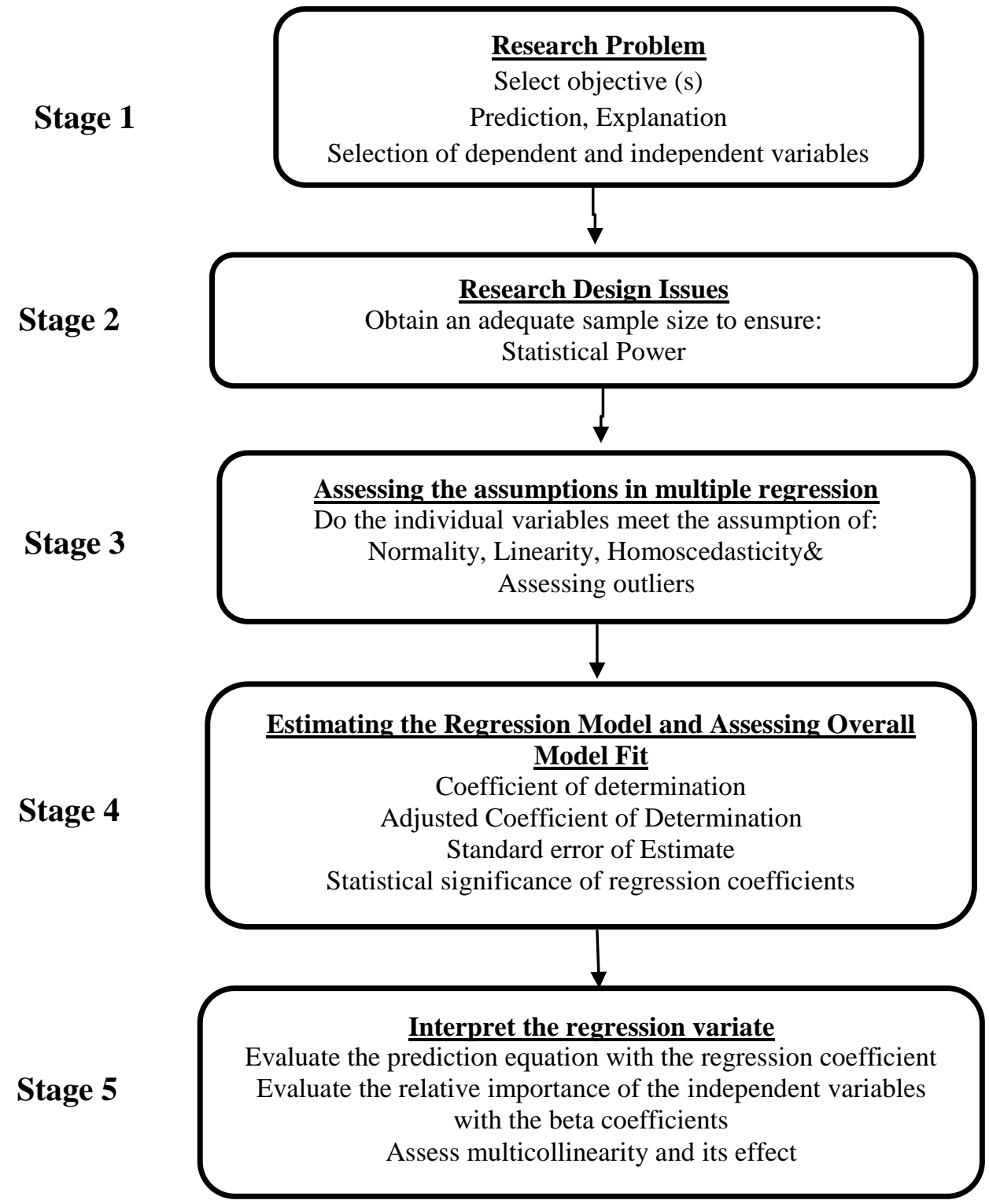

Figure 2. Five-stages in multiple linear regressions with regards to the need of study (Sources: Hair et al., 2010)

\section{- $\quad$ Stage 1: Objectives of Multiple Linear Regression}

A multiple linear regression is used to answer the three research hypotheses in this study that is to determine if there is a significant relationship between school change orientation and school climate. Specifically, the research hypotheses which are: 
$\mathrm{Ho}_{1}$ : There is no significant relationship between Faculty Openness to Change and School Climate.

$\mathrm{Ho}_{2}$ : There is no significant relationship between Principal Openness to Change and School Climate.

$\mathrm{Ho}_{3}$ : There is no significant relationship between Community Press for Change and School Climate.

Thus, four following variables were identified to be included in the analysis (Table 15).

Table 15

Variables in the Analysis

\begin{tabular}{ll}
\hline Types of variable & Variable Name \\
\hline Dependent variable & School Climate: \\
& Obtained by calculating the mean score for every 6 \\
& constructs in the school climate questionnaire \\
\hline Independent variable & Faculty Openness to Change \\
& Principal Openness to Change \\
& Community Press for Change \\
\hline
\end{tabular}

\section{- $\quad$ Stage 2: Research design of a Multiple Regression Analysis}

The study obtained 246 respondents which participated in the study. All 246 respondents provided complete responses, resulting in 246 observations available for the analysis. The first issue arises in the research design concerns on the sample size. This is because determination of sample size also affects the generalizability of the results by the ratio of observations to independent variables. Different authors tend to give different guidelines concerning the adequate number of sample size in conducting the multiple regression analysis.

A general rule is that the ratio should never fall below 5:1, meaning five observations are made for each independent variable in the variate (Hair et al., 2010). Although the minimum ratio is $5: 1$, the desired level is between 15 to 20 observations for each independent variables. When this level is reached, the result should be generalizable since sample is representative. Since study consist of 3 independent variables with 246 observations, it meets the guidelines for adequate sample size with an actual ratio of 1:82. Meanwhile, Tabachnick and Fidell (2007) gives a formula for calculating sample size requirement, taking into account the number of independent variables that wished to be used: $n>50+8 m$ (where $m=$ number of independent variables). Thus, this study has not violated this assumption since $n(246)>74(50+8 * 3)$. Hence, the proposed regression analysis was deemed sufficient to identify not only statistical significant relationship but also relationships that had managerial significance. 


\section{- $\quad$ Stage 3: Assumptions in Multiple Regression Analysis}

Meeting the assumptions of regression analysis is essential to ensure that the results obtained are truly representative of the sample and that researcher obtain the best result possible. Any serious violations of the assumption must be detected and corrected if possible. Analysis to ensure the research is meeting the basic assumptions of regression analysis involved two steps: (1) testing the individual dependent and independent variables and (2) testing the overall relationship after model estimation.

Some statistics writers suggest that the extreme outliers' observations should be removed (Pallant, 2010). Thus, first, researchers removed the three extreme outliers (Obs $=59,30,9,216)$. Boxplot are conducted again, and 1 extreme outlier were found (Obs =190). Outliers' are deleted again, hence giving a total sample of 221 respondents only (Figure 4.15). Finally, not much outlier was found. Hair et al. (2010) stated that those outliers are not necessarily bad in the sense that they must be deleted. However, Pallant (2010) suggest an appropriate action on how to handle these remaining outliers. Descriptive table can give an indication on how much a problem these outlying cases are likely to be. The three independent variables are checked through the $5 \%$ trimmed mean. Pallant (2010) stated that if the trimmed mean and mean values are very different, researcher need to investigate this outliers / points further.

For Faculty Openness to Change, the two mean values $(4.2127,4.2150)$ are very similar. For Principal Openness to Change variable, the two mean values $(4.5754,4.5720)$ also very similar. Finally, looking at the variable Community Press for Change, the two mean values $(4.2376,4.2425)$ are very similar too. The fact that the values are not too different from the remaining distribution, researcher decided to retain these cases in the data file.

\section{- Stage 4: Estimating the Regression Model and Assessing Overall Model Fit}

With the regression analysis specified in terms of dependent and independent variables, the sample deemed adequate for the objectives in the study, and the assumption assessed for the individual variables, model building process now proceeds to estimation of the regression model and assessing the overall model fit.

Table 16

Correlation between variables

\begin{tabular}{llll}
\hline & SC & FOC & POC \\
\hline FOC & $.179^{*}$ & & \\
POC & $.205^{*}$ & $.578^{*}$ & $.517^{*}$ \\
CPC & $.314^{*}$ & $.569^{*}$ & .5 \\
\hline
\end{tabular}

Note: ${ }^{*} p<.001$ 


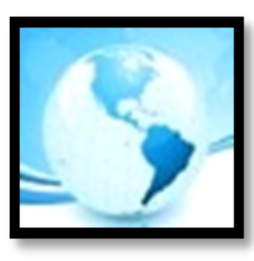

\section{MALAYSIAN ONLINE JOURNAL OF EDUCATIONAL MANAGEMENT (MOJEM)}

Table 17

Predicting School Climate

\begin{tabular}{|c|c|c|c|}
\hline Predictor & $\beta$ & SE & $95 \% \mathrm{Cl}$ for $\rho$ \\
\hline Faculty Openness to Change (FOC) & -.012 & .036 & $-.082, .059$ \\
\hline Principal Openness to Change (POC) & .023 & .027 & $-.030, .077$ \\
\hline Community Press for Change (CPC) & $.103^{*}$ & .029 & $.047, .160$ \\
\hline
\end{tabular}

Note: ${ }^{*} \mathrm{p}<.001, \mathrm{R}^{2}=.101$

Faculty Openness to Change, Principal Openness to Change and Community Press for Change are used to predict the school climate. The correlations of the variables are shown in Table 16. As can be seen, all correlation was statistically significant $(p<.001)$.

The prediction model was statistically significant, $F(3,217)=8.160, p<.001$, and accounted for approximately $10.1 \%$ of the variance of school climate $\left(R^{2}=.101\right.$, Adjusted $\left.R^{2}=.089\right)($ Table 17). Meanwhile, the standard error of estimate is another measure of the accuracy in the predictions. It also represents an estimate of the standard deviation of the actual dependent values around the regression line (Hair et al., 2010). Since standard error (Se) in the study shows small values ( $\mathrm{Se}=.155$ ) indicating that model is significant. However, only one predictor variable was found to be positively significant correlated with the school climate, which is the community press for change $(\beta=0.103, p<.001, \mathrm{Cl}=.047, .160)$. Since the coefficient is positive, thus it indicates that more positive perception of community press for change, increase perception on school climate.

Next is to evaluate the variate for the assumptions of regression analysis. In evaluating the estimated equation, the researcher considered statistical significance. Hair et al. (2010) also stated that at this point, researcher also should address two basic issues: (1) meeting the assumptions underlying regression and (2) identifying the influential data points.

Finally, the researchers examined the individual variables for meeting the assumptions required for regression analysis. However, the researcher must also evaluate the variate for meeting these assumptions as well. As stated before, those three assumptions should be conducted for testing the overall relationship after model estimation. Specific tests for each assumption should be conducted to check for violations.

\section{- Stage 5: Interpreting the Regression Variate}

With the model estimation completed, the regression variate specified, and the diagnostic tests that confirmed the appropriateness of the results administered, then the researchers examined the predictive equation based on the significant independent variable. Since only one predictor variable was found to be statistically significant, the predictive equation would be written:

$$
\mathrm{Y}=2.185+0.103 \text { (Community Press for Change) }
$$




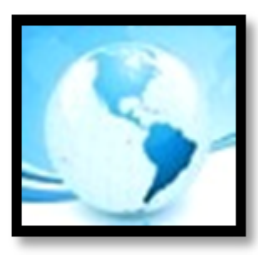

\section{MALAYSIAN ONLINE JOURNAL OF EDUCATIONAL MANAGEMENT (MOJEM)}

With this equation, the expected school climate perception for any teachers could be calculated if that perception on community press for change is known.

In this stage also, it is important to check and measuring the degree and impact of multicollinearity. In any interpretation of the regression variate, the researcher must be aware of the impact of multicollinearity (Hair et al., 2010). Multicollinearity occurs when independent variables used in a multiple regression are highly correlated. This problem commonly occurs in social sciences particularly because some of them maybe measuring under the same phenomenon. Highly collinear variables can distort the result substantially or make them quite unstable and thus not generalizable. Two measures are available for testing the impact of collinearity which are tolerance statistics (TOL) and variance inflation factor values (VIF). Multicollinearity problem occurs when TOL $<0.1$ and VIF $>$ 10. Finally, looking at the Table 18 , suggesting no multicollinearity problem, thus coefficient interpretation is generalizable.

Table 18

Collinearity Statistics

\begin{tabular}{ccc}
\hline \multirow{2}{*}{ Independent Variables } & \multicolumn{2}{c}{ Collinearity Statistics } \\
\cline { 2 - 3 } & Tolerance & VIF \\
\hline Community Press for Change & .623 & 1.605 \\
\hline
\end{tabular}

\section{DISCUSSIONS AND CONCLUSION}

One needs to study the existing strengths and weaknesses in the organization when designing or implementing change initiatives in an organization. The success rate of the change initiatives is higher once we are aware of these preconditioned aspects. Based on the models of change orientation discussed earlier, there are several preconditioned aspects that have influence on the orientation and management of changes. In the context of this study, the preconditioned aspects are faculty openness to change, principal openness to change and community press for change.

Findings of this study revealed that the overall practice level of the dimensions in change orientation of national primary schools is high. This situation shows that teachers, school leaders and community around the school are very positive and open attitude toward changes and innovation. Thus, primary schools have very strong basis to plan and implement change efforts.

This study also found the practice level of the dimensions in change orientation according to priority is principal openness to change, community press for change and faculty openness to change. All of these dimensions are at a high level. Therefore, school's community should take this opportunity to ensure that changes initiatives or programmes that will be implemented can be accepted by all parties. This strength when used in an effective manner will produce encouraging results. These findings are supported with findings of previous researches that concluded with teachers realizing and understanding the importance of change and innovation in education (Wheatly, 1992; Huber \& Glick, 1993; Fullan \& Suzanne, 1992; Abdul Shukor, 2004; Hargreaves, 2005; Mohd Izham \& Sufean, 2007; Ghavifekr et al., 2013a). 


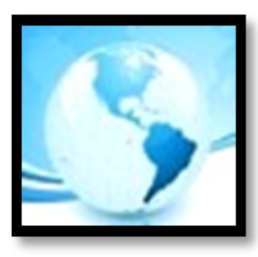

\section{MALAYSIAN ONLINE JOURNAL OF EDUCATIONAL MANAGEMENT (MOJEM)}

In the context of this study, the level of practices on the faculty openness to change dimension is found to be high. This situation portrays majority of the teachers in national schools in Keramat District to have an open and positive attitude towards change. Teachers are perceived to be welcoming towards change programmes that are going on in schools. They are very good examples to other community because they embrace and are open to change and innovation. The findings show that teachers view confrontation and conflict as not being the correct solution in dealing with change conflicts. This implies that although some change initiatives might cause some resistance, teachers are open to suggestions and strategies to make change work for the benefits of them and the students. This view is in line with Jamil (2001) who states that actual changes will not take effect in the organization if its people do not have positive attitude and are not sure of the need for the change. Changes will result in something that is expected from it if it is assisted with increased consciousness and positive attitude among teachers.

In this study, the level of practices on the principal openness to change dimension is found to be high. School heads are found to be supportive and open of change in schools. As leaders in schools, they are very committed to change efforts and embraces change initiatives that are mandated by the Ministry or even if it was initiated internally by themselves. Principals and school heads play a significant role in ensuring success of change initiatives and programs. School heads who are open to change are the ones willing to challenges the status quo and is willing to disrupt the equilibrium within the school for a better change for the school. Findings also show the highest mean is 4.54 for principal openness to change. This indicates teachers perceived their principal or school leader as having the most effect on their perception on change orientation. Results show that in primary schools, schools leaders need to acquire knowledge, skills and the leadership to ensure positive change initiatives. These findings supports the previous researches (Beer, Eisenstat, \& Spector, 1990; Ghavifekr et al., 2013b; Kotter, 1996; Kotter\& Cohen, 2002) on the need for school leaders to have their own strategy or action plan to ensure educational innovations are accepted and at the same time increase teachers' readiness and lesson resistance toward change (Fullan, 2011; Ogawa \& Bossert, 1995).

Findings from this study indicate that level of practices on the community press for change dimension is high. Stakeholders, especially parents, usually voice their ideas and suggestions through the Parents and Teachers Associations (PTA) in schools. Their ideas and suggestions are found to often initiate and produce change in schools. School heads and teachers are open to ideas and suggestions given by parents. The findings of this study prove that community outside of schools are very much concerned about change initiative and innovation. This is synchronized with other researches that find organizations need to be sensitive and aware of pressures from outside on the issue of change. Outside influences will affect employee attitudes towards work that they do. This is in line with suggestion by Ab Aziz (2003) that leaders and members of the organization must respond proactively to any reaction and external pressures.

However, this study found that the outside community does put pressure on schools to implement change. This is consistent with other findings by Huber and Glicks (1993), and Woodman (2014), which suggest that every organization needs to adapt the organizational environment relationship paradigm and react critically on how these organizations can operate effectively with the external pressure.

Similar to Adel Tajasom and Zainal Ariffin (2011) research, findings of this study reveal that the overall practice level of the dimensions in school climate of national primary schools is moderate except for the dimension disengaged teacher behaviour which is at a low level. The behaviours of the school heads are moderately 


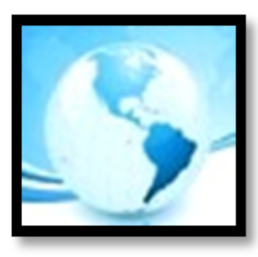

\section{MALAYSIAN ONLINE JOURNAL OF EDUCATIONAL MANAGEMENT (MOJEM)}

supportive, directive and restrictive. They are either playing it safe or have no particular strong leadership style which contributes towards the positive and open school climate. Neither have they had a strong leadership style that give negative impact on the climate of schools. The behaviours of teachers in Keramat District primary schools are neither too collegial nor intimate in their relationship with each other in schools. However, teachers are found to be very attached and dedicated to their professions as educators in the schools. They are also very engaged and serious about their responsibilities as teachers and staff in schools which explains the low level of disengaged teacher behaviour dimension.

The findings discussed throughout this paper on the practice level of the dimensions in school climate are supported with findings of previous research that concluded that school head behaviour (supportive, directive and restrictive) and teacher behaviour (collegial, intimate and disengaged) as one of the elements that have great impact on climate in schools (Hoy, Tarter, \& Bliss, 1990; Hoy, Tarter, \& Kottkamp, 1991; Brodbeck, 2002; Hallinger, Heck, \& Murphy, 2014 ; Brightman \& Moran, 2001; Ogawa \& Bossert, 1995).

In this study, one dimension of change orientation is related with school organizational climate. It is found that the community's pressure for change will affect the dimensions of school climate. However, generally, principal or school heads and teachers have yet to have a strong impact and influence on school climate. While this study will add to the existing literature on change and climate, it is hoped that educational authorities, school heads, teachers and stakeholders are to be provided with insights into the dynamic relationship between change and climate resulting in better change management and positive climate in schools that contribute to student achievement.

\section{REFERENCES}

Ab. Aziz Yusof. (2003). Organizational Behaviour: Theories, Issues and Implications. Petaling Jaya: Prentice Hall.

Abdul Shukor Abdullah. (2004). Superior leadership milestone excellent management education. Journal of Educational Management and Leadership,14 (1), 18-33.

Adel Tajasom \& Zainal Ariffin Ahmad. (2011). Principals' leadership style and school climate: teachers' perspectives from Malaysia, International Journal of Leadership in Public Services, 7 (4), 314 - 333.

Amrit, T., Cohen, J., Guffey, S. \& Alessandro, A.H. (2013). A Review of School Climate Research. Review of Educational Research, 83(3), 357-385.

Anderson, S. E. (1997). Understanding teacher change: Revisiting the concerns based adoption model. Curriculum Inquiry, 27(3), 331-367.

Beer, M., Eisenstat, R. M., \& Spector, B. (1990). Why Change Program Don't Produce Change. Harvard Business Review. 68(6), 158-166.

Brightman, B. K. \& Moran, J.W. (2001). Leading organizational change. Career Development International, 6 (2), 111-119.

Bulach, C. R. (2001). A 4-Step process for identifying and reshaping school culture: Principal Leadership. Middle School Ed., 1(8), 48-51. 


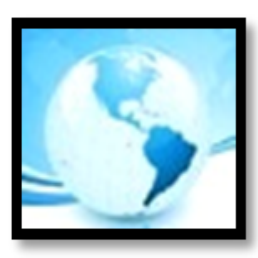

\section{MALAYSIAN ONLINE JOURNAL OF EDUCATIONAL MANAGEMENT (MOJEM)}

DuFour, R. \& Eaker, R. (1998). Professional learning communities at work: Best practices for enhancing student achievement. Bloomington, IA: National Educational Service.

Elmore, R. (2004). School reform from the inside out. Cambridge, MA.: Harvard University Press.

Evans, R. (1996). The Human Side of School Change: Reform, Resistance and the Real-life Problems of Innovations. San Francisco: Jossey-Bass.

Fullan, M. (1991). The new meaning of educational change. New York(NY): Teachers College Press.

Fullan, M.G. \& Suzanne, S. (1992). The new meaning of educational change. London: Casell Education Ltd.

Fullan, M.G. (1995). The limits and the potential of professional development. In T. Guskey and M. Huberman (Eds.), Professional Development in Education: New Paradigms and Practices (pp. 253-267). New York: Researchers College Press.

Fullan, M. (2010). All systems go: The change imperative for whole system reform.

Thousand Oaks, CA.: Corwin Press; Toronto: Ontario Principals Council.

Fullan, M. (2011). The moral imperative realized. Thousand Oaks, CA: Corwin Press; Toronto: Ontario Principals Council.

Ghavifekr, S., Afshari, M., Saedah, S., \& Ahmad, Z.(2013a). Vision- Driven Strategies and Policies for Managing Educational Systemic Change: A Qualitative Analysis. Australian Journal of Basic and Applied Sciences, 7(4), 333-341.

Ghavifekr, S., Afshari, M., Saedah, S., \& Segar.K. (2013b). ICT Application for Administration and Management. Procedia - Social and Behavioral Sciences Elsevier, 103 (2013), 1344 -1351.

Hair, J.F, Black, W.C., Babin, B.J., \& Anderson, R.E. (2010). Multivariate Data Analysis. Seventh Edition. Prentice Hall, Upper Saddle River, New Jersey.

Hamzah, M.I., A Ismail \& MA Embi. (2009). The impact of technology change in Malaysian smart schools on Islamic education teachers and students. International Journal of Human and Social Sciences, 4 (11), 824-836.

Hallinger, P. \& Heck (1998). Exploring the principal's contribution to school effectiveness: 1980-1995. School Effectiveness and School Improvement, 9 (2), 157-191.

Hallinger, P., Heck, R. H., \& Murphy, J. F. (2014). Teacher Evaluation and School Improvement: An Analysis of the Evidence. Educational Assessment, Evaluation and Accountability, 26(1), 5-28.

Halpin, A. W., \& Croft, D. B. (1966). The Organizational Climate of Schools. Chicago: Midwest Administration Center of the University of Chicago.

Hargreaves, A. (2005). Educational change take ages: life, career and generational factors in teachers' emotional response to educational change. Teaching and Teacher Education, 21, 967-983. 


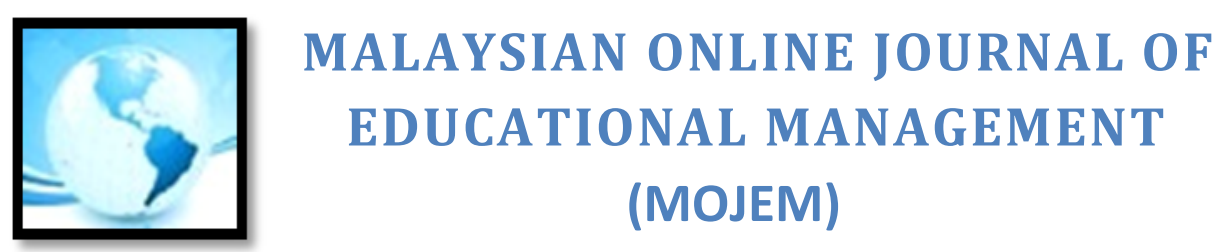

Harris, P.R. (2013). Developing high performance leaders: a behavioural science guide for the knowledge of work culture. New York: Routledge Taylor \& Francis Group.

Hayal, K. (2013). Reducing teacher resistance to change and innovations. Retrieved from http://linc.mit.edu/linc2013/proceedings/Session10/ Session10 Koksal .pdf.

Hoy, W. K., Tarter, C. J., \& Bliss, J. (1990). Organization climate, school health, and effectiveness: A comparative analysis. Educational Administration Quarterly, 26, 260-279.

Hoy, W. K., Tarter, C. J., \& Kottkamp, R. B. (1991). Open schools/healthy schools: Measuring organizational climate. Beverly Hills, CA: Sage.

Hoy, W. K. \& DiPaola, M. F. (Eds.) (2009). Studies in school improvement. Volume 8 in the Series -- Research and Theory in Educational Administration. Charlotte, NC: Information Age Publishing.

Huber, G.P. \& Glick, W.H. (1993). Organizational change and redesign: ideal and insight for improving performance. New York: Oxford University Press.

Hussein Ahmad. (2012). Mission of Public Education in Malaysia: The challenge of Transformation. Kuala Lumpur: University of Malaya Press.

Huy, Q.N. (2001). Time, temporal Capability and Planned Change. Academy of Management Review. 26(4), 601-23.

Jamil Ahmad. (2001). Culture of Change Among Teachers in Schools: An Evaluation. Unpublished Ph.D. Thesis. National University of Malaysia.

Kearney, S., \& Smith P. A. (2008). A theoretical and empirical analysis of change orientations in schools. In Wayne

K. Hoy \& Michael DiPaola (2009). Studies in School Improvement. Greenwich, CN: Information Age.

Kerlinger, F.N. (1986). Foundations of behavioral research ( $3^{\text {rd }}$ ed.). Fort Worth, TX: Holt, Rinehart, and Winston.

Kotter, J. (1996). Leading change. Boston: Harvard Business School Press.

Kotter, J. P. \& Cohen, D. S. (2002). The heart of change; Real-life stories of how people change their organizations. Boston, MA: Harvard Business School Press.

Loukas, A. (2007). What is school climate? Leadership Compass, 5(1), 1-3.

Mohd Izham, M.H. \& Sufean. H. (2007). Challenges and planned changes in smart school practice: Use SSMS as instructional technology in teaching and learning, School Climate, 4, 71-91.

National School Climate Council. (2014). School Climate. Retrieved from http://www.schoolclimate.org/climate/.

Nor Hasnida Md Ghazali, Baharim Yaakub \& Afian Akhbar Mustam. (2012). Why Do We Need To Change?: Teachers' Attitude Towards School-Based Assessment System. SCR London's First International Conference on Social Sciences and Humanities in the Islamic World. Retrieved from : http://www.academia.edu/1481049/_why__ do_we_need_to_ change_teachers_attitude_towards_school-based_assessment_system on 11th September 2014. 


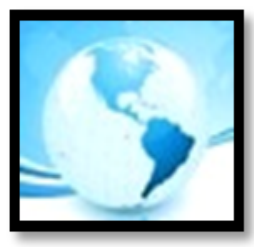

\section{MALAYSIAN ONLINE JOURNAL OF EDUCATIONAL MANAGEMENT (MOJEM)}

Ogawa, R., \& Bossert, S. (1995). Leadership as an organizational quality. Educational Administration Quarterly, 31, 224-243.

Pallant, J. (2010). SPSS survival manual: A step by step guide to data analysis using SPSS. McGraw-Hill International.

Sharifah Md Nor \& Samsilah Roslan. (2009). Turning around at-risk schools: what effective principals do. International Journal on School Disaffection, 6(2), 21-29.

Stanford, B. (1998). Charting school change: improving the odds for successful school reform. California: Corwin Press Inc.

Smith, P. A. (2002). The organizational health of high schools and student proficiency in mathematics. The International Journal of Educational Management, 16 (2/3), 98-104.

Tabachnick, B. G., \& Fidell, L. S. (2007). Using multivariate statistics. Boston: Pearson/Allyn \& Bacon.

Vakola, M. (2012). What's in there for me? Individual readiness to change and the perceived impact of organizational change. Leadership \& Organization Development Journal, 35 (3), 195 - 209.

Wheatley, M. (1992). Leadership and the New Science. New York: Berrett-Koehler Publishers.

Woodman, R. W. (2014). The science of organizational change and the art of changing organizations. The Journal of Applied Behavioral Science, 50(4), 463 477. 